\title{
ECO-BALANCE FEATURES AND SIGNIFICANCE OF HEMIHYDRATE PHOSPHOGYPSUM REPROCESSING INTO GYPSUM BINDING MATERIALS
}

\author{
Sergejus Gaidučis ${ }^{1}$, Romualdas Mačiulaitis ${ }^{2}$, Antanas Kaminskas ${ }^{3}$ \\ ${ }^{1,2}$ Dept of Building Materials, Vilnius Gediminas Technical University, \\ Saulètekio 11, LT-102223 Vilnius, Lithuania \\ ${ }^{3}$ Institute of Thermal Insulation, Vilnius Gediminas Technical University, \\ Linkmenu g. 28, LT-08217 Vilnius, Lithuania \\ E-mail: ${ }^{1}$ sergejus.gaiducis@gmail.com; ${ }^{2}$ romualdas.maciulaitis@st.vgtu.lt; ${ }^{3}$ envestat@takas.lt \\ Received 26 June 2008; accepted 4 Dec 2008
}

\begin{abstract}
The classification and grouping of materials investigation according to raw material's nature and product purpose (use) was conducted by using comparative material energetic usefulness and its production ecobalance analytical methods. Energy expenditures and pollution emissions into the environment were studied and compared to analogical purpose materials. One of the most economically perspective technogenic waste - extractive hemihydrate phosphogypsum was investigated. Two technological production streams of phosphogypsum were studied. It was found, that the energy needs for production of analogical purpose materials (wall partitions) differ significantly. The nature of raw materials has an influence on energetic usefulness. The most effective materials according to their nature, energetic usefulness and environmental protection are mineral ones, especially if they are made with technogenic inorganic waste materials. The best results, from the energetic and ecological point of view, are obtained by using the waste raw material - extractive hemihydrate phosphogypsum. Its reprocessing energy expenditures and pollutant emissions into the environment are several times less, than for other analogical purpose and properties wall materials, also with less environmental pollution. Products made from reprocessing extractive hemihydrate phosphogypsum can replace other energy consuming articles for wall partitions.
\end{abstract}

Keywords: phosphogypsum, acidic admixtures, neutralization additives, mechanical activation, gypsum cement, energetic usefulness, ecobalance.

\section{Introduction}

The construction industry is one of the largest energy consumers, whose activities have a direct influence on the condition of the environment. At present, the EU countries and Lithuania among them, manufacture many analogical purpose materials (e.g. wall materials), the energy expenditures and pollutant emissions of which into the environment are very high. The construction industry, using large amounts of energy contributes very much too global climate warming and is a growing threat to the whole world. So, that is why we need to look for new methods to lower the use of energy and reduce the amounts of gaseous emissions.

Environmental pollution mitigation and technogenic waste reprocessing problems are being widely investigated in Lithuania (Gimbutaite, Venckus 2008; Šeduikytė, Bliūdžius 2005; Rudžionis, Ivanauskas 2004; Čygas, Laurinavičius 2003; Jakowlew et al. 1997), and also in other countries (Kosior-Kazberuk, Lelusz 2007; De Oliveira et al. 2006; Buchanan, Honey 1994; Suzuki et al. 1995; Debnath et al. 1995; Kohler 1986). At present, due increasing production volumes, increasing numbers of transport vehicles and other factors, the pollution of the environment by technogenic waste has increased conside- rably. Much more $\mathrm{CO}_{2}$ is being emitted into the atmosphere and the amounts of waste which could be reprocessed find its way to landfills. Reprocessing and reuse of technogenic waste is very important from the environmental pollution mitigation point of view, especially if accumulated waste energy is present in the waste. An example of such waste could be extractive hemihydrate phosphogypsum (further on in the text - E-PG).

EU Directive 2002/91/EC on increasing the energetic effectiveness of buildings especially emphasizes the need for lowering energy expenditures and expanding non-traditional sources of energy (wind, solar, biofuel) as well as wasting energy. The implementation of this Directive is compulsory for all EU countries from the year 2006. The energy restructurisation and environmental pollution lowering problems were determined as an immediate task in forming EU economical development strategy up till the year 2020. It is foreseen, that up to the year $2020 \mathrm{CO}_{2}$ emissions into the environment should be reduced by at least 20\% (based on 2006 level) in each EU country. The long and intense discussion in the world ended when scientists prepared a report to the UN on global warming causes and it has been approved. It was acknowledged, that one of the most important causes of this phenomena was all mankind activities. 
One of the methods to determine the damage which construction material production has on energetic usefulness and environmental pollution is the creation of material production ecobalances (life cycle assessment), which under present conditions, aside national economical balances becomes a strategic economical and ecological problem solving and managing instrument. The building's energetic usefulness increase process can be conditionally divided into 4 major stages:

1. Construction materials production energetic usefulness increase by using ecobalances which take into account extraction of raw materials and its benifications.

2. Improvement of construction projects and technologies.

3. Maintenance of buildings.

4. Utilization of demolished buildings after the end of their use.

All the investigations conducted up till now about the complication and analysis of ecobalancies separate stages (i. e. interrelationships) have not been properly evaluated (Čiurpinskas, Martinaitis 1997; Dzenajavičienè 2001; Kryževičienè et al. 2001; Martinaitis 1997; Gedgaudas, Martinaitis 1996; Martinaitis 1999).

The use of technogenic waste has a large influence on construction material production integral ecobalance (Kaminskas 2002; Rimkevičius 2003; Kaminskas, A., Kaminskas, R. 2003; Žurauskas 2002). One of the most prospective materials in this respect is the extractive hemihydrate phosphogypsum (E-PG); it was chosen to investigate the increase of technological material energetic usefulness. It is one of the most abundant mineral wastes, the stacks of which are growing at an increasing rate, while its use is not solved up till now, because the available technologies for its use require high energy expenditures, then for natural raw materials (Kaminskas A., Kaminskas R. 2003). JSC "Lifosa" disposes more than 1 million tons of E-PG each year to stackpiles, thus losing about $160 \mathrm{kWh}$ of accummulated chemical waste energy with each ton, which due to the interaction with the surrounding moisture decay. In such a way about $160 \mathrm{mln} \mathrm{kWh}$ of waste energy is lost. As time goes on, enormous stackpiles of phosphogypsum have arisen (Fig. 1).

When contaminated with acidic admixtures, phosphogypsum is disposed to stacks atmospheric precipitation leaches them out into the soil and ground waters. Besides, that phosphogypsum is transported to the stacks about $2 \mathrm{~km}$ from the plant by trucks which use up large amounts of fuel and emit a corresponding amount of $\mathrm{CO}_{2}$ into the atmosphere.
The acidic admixtures present in gypsum binding materials based on phosphogypsum have the largest influence on its properties (Radwan, Heikal 2005). That is unreacted apatite, remains of $\mathrm{H}_{3} \mathrm{PO}_{4}$ and $\mathrm{H}_{2} \mathrm{SO}_{4}$, iron and aluminum salts (Rimkevičius 2003). These are the admixtures which inhibit hydration and hardening processes, also destabilize such an important phosphogypsum binding material property like setting time. Due to the above-mentioned causes, also to the harmful impact on human health of some other admixtures present in E-PG, it cannot be used for production of gypsum binding materials. That is why all the harmful admixtures need to be neutralized (i. e. converted to insoluble, nontoxic compounds) before the waste is used for producing construction materials. Various alkaline additives can be applied as neutralizers (Kaminskas 2002; Rimkevičius 2003; Radwan, Heikal 2005).

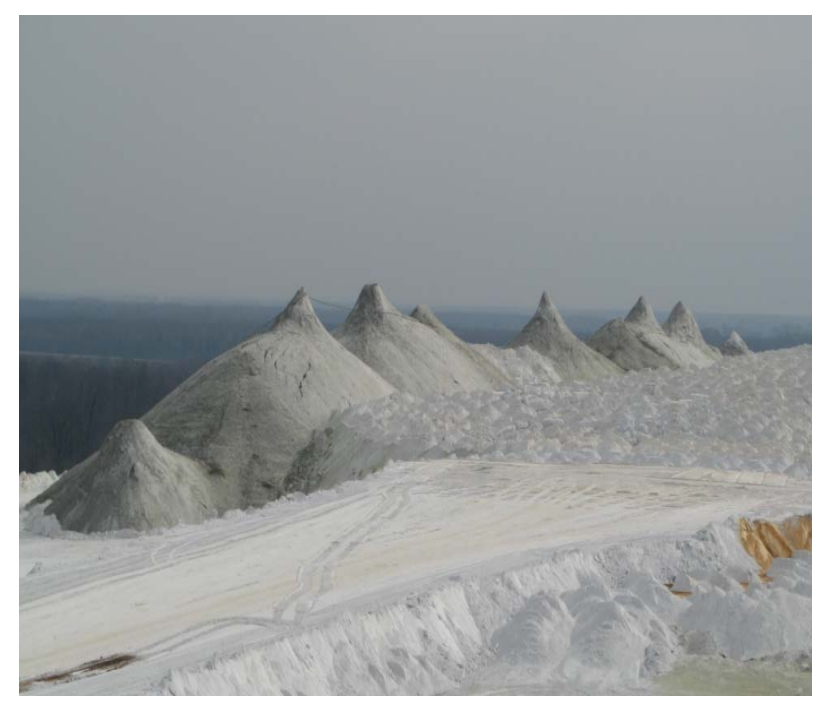

Fig. 1. Dihydrate phosphogypsum stacks

In spite of the fact, that a lot of attention (Kaminskas et al. 2007; Kaziliūnas, Bačauskienè 2007; Rimkevičius, Kaminskas 2003; Degirmenci 2008; Singh 2002; Singh 2003; Degirmenci et al. 2007; Žvironaitè et al. 2008) is being paid to phosphogypsum research, practically no continuous industrial reprocessing of it exists up till now.

The aim of this investigation was to analyze the influence of various construction materials nature on energy expenditures and pollutant $\left(\mathrm{CO}_{2}\right)$ emissions into the environment, also to investigate the abundant technogenic waste (hemihydrate phosphogypsum) reprocessing possibilities into construction articles as well as to compare ecobalance indices effectiveness of various types of wall partitions.

Table 1. E-PG characteristics

\begin{tabular}{c|c|c|c|c|c}
\hline E-PG sort & Humidity, $\%$ & $\mathrm{pH}$ & Temperature, ${ }^{\circ} \mathrm{C}$ & Initial setting time, min. & Final setting time, min. \\
\hline E- $-\mathrm{PG}_{\mathrm{K}}$ & 35 & 2.48 & 61 & 45 & 70 \\
\hline $\mathrm{E}-\mathrm{PG}_{\mathrm{M}}$ & 26 & 2.26 & 65 & 35 & 65 \\
\hline
\end{tabular}


Table 2. Raw material chemical composition

\begin{tabular}{|c|c|c|c|c|c|c|c|c|c|c|c|}
\hline \multirow{2}{*}{$\begin{array}{c}\text { Raw } \\
\text { material }\end{array}$} & \multicolumn{11}{|c|}{ Chemical compounds, $\%$} \\
\hline & $\mathrm{SO}_{3}$ & $\mathrm{CaO}$ & $\mathrm{Al}_{2} \mathrm{O}_{3}$ & $\mathrm{Fe}_{2} \mathrm{O}_{3}$ & $\mathrm{P}_{2} \mathrm{O}_{5 \mathrm{~g}}$ & $\mathrm{P}_{2} \mathrm{O}_{5 \mathrm{ws}}$ & $\mathrm{F}$ & $\mathrm{MgO}$ & $\mathrm{SiO}_{2}$ & $\mathrm{~K}_{2} \mathrm{O}$ & $\begin{array}{c}\text { Ignition } \\
\text { losses }\end{array}$ \\
\hline $\mathrm{E}-\mathrm{PG}_{\mathrm{K}}$ & 55.75 & 39.04 & 0.22 & 0.13 & 1.44 & 0.56 & 0.53 & traces & - & - & 2.33 \\
\hline $\mathrm{E}-\mathrm{PG}_{\mathrm{M}}$ & 53.6 & 37.18 & 0.03 & - & 1.3 & 0.4 & 0.12 & traces & 4.76 & - & 2.61 \\
\hline Opoka & 0.37 & 16.3 & 1.83 & 0.74 & - & - & - & 0.12 & 66.15 & 0.23 & 14.26 \\
\hline
\end{tabular}

Note: $g$ - general, ws - water soluble

Table 3. Formation mass properties

\begin{tabular}{l|c|c|c|c}
\hline \multicolumn{1}{c|}{ Formation mass composition } & $\mathrm{pH}$ & $\mathrm{w} / \mathrm{s}$ & Setting time initial, min. & Final setting time, min. \\
\hline Activated $\mathrm{E}-\mathrm{PG}_{\mathrm{K}}$ without additivies & 2.56 & 0.35 & 0,5 & 1.0 \\
\hline Activated $\mathrm{E}-\mathrm{PG}_{\mathrm{K}}+3 \%$ opoka & 5.54 & 0.35 & 17 & 36 \\
\hline Activated $\mathrm{E}-\mathrm{PG}_{\mathrm{K}}+5 \%$ opoka & 5.99 & 0.35 & 21 & 29 \\
\hline Activated $\mathrm{E}-\mathrm{PG}_{\mathrm{K}}+10 \%$ opoka & 6.25 & 0.35 & 31 & 49 \\
\hline Activated $\mathrm{E}-\mathrm{PG}_{\mathrm{K}}+15 \%$ opoka & 6.8 & 0.35 & 28 & 51 \\
\hline Gypsum cement from $\mathrm{E}-\mathrm{PG}_{\mathrm{K}}$ & 11.46 & 0.32 & 22 & 71 \\
\hline Gypsum cement from $\mathrm{E}-\mathrm{PG}_{\mathrm{M}}$ & 11.65 & 0.32 & 18 & 65 \\
\hline
\end{tabular}

\section{Materials and methods}

Autoclave cellular concrete plant (YTONG) ecobalance evaluation method (Hums 1994) was used for analytical investigations. According to this method, the analytical investigations were conducted in 3 steps:

- A environmental polluting material balance (life cycle inventory) is drawn up, which shows how much and what kinds of pollutants arise during the construction material production and during its maintenance period;

- The influenced objects are revealed (water, air pollution, increase of acidity, etc.);

- Environmental impact assessment (life cycle analysis), which shows the relative and general quantitative pollutant influence comparison.

Various foreign country scientists' published investigation results and also our data were used for conducting the comparative material usefulness and its production ecobalance analytical investigation by classifying and grouping them according to the nature of the raw material and article.

In the investigation we used freshly removed from the conveyer, warm E-PG with a $\mathrm{CaSO}_{4}$ amount up to $95 \%$. The two technological E-PG production streams using Kovdor apatite $\left(\mathrm{E}-\mathrm{PG}_{\mathrm{k}}\right)$ and the $10 \% \mathrm{E}-\mathrm{PG}_{\mathrm{K}}$ and $90 \%$ Morocco apatite $\mathrm{E}-\mathrm{PG}_{\mathrm{M}}$ mixture were used in the investigation. The E-PG characteristics are given in Table 1 .

An amount of E-PG was taken from the conveyer which could be used up in 1 hour time in the investigations. The aim was to avoid E-PG hydration and formation of hard lumps, which makes dosage and feeding into the disintegrator much harder.

In this research study we used Portland cement and opoka mixture as a neutralizing addititive. High initial strength Portland cement CEM I 42.5 R; LST EN 197 - 1: 2001 (Cem) with a specific surface area of $357.4 \mathrm{~m}^{2} / \mathrm{kg}$ was chosen for use in this investigation. The mineral composition of clinker used for manufacturing cement was as follows: $\mathrm{C}_{3} \mathrm{~S}-61 \% ; \mathrm{C}_{2} \mathrm{~S}-19 \% ; \mathrm{C}_{3} \mathrm{~A}-7 \% ; \mathrm{C}_{4} \mathrm{AF}-13 \%$.

Beside the Portland cement we also used Stoniškiu quarry milled opoka in the mixture. It is an amorphous, active additive with a specific surface area of $1411.6 \mathrm{~m}^{2} / \mathrm{kg}$. The Portland cement and opoka ratio was 1:1. The raw material chemical composition is in Table 2.

The investigation of E-PG reprocessing possibilities into construction materials was conducted as follows: specimens were formed using activated $\mathrm{E}-\mathrm{PG}_{\mathrm{K}}$ without additives, activated $\mathrm{E}-\mathrm{PG}_{\mathrm{K}}$ with opoka additive as well as selected identical E- $\mathrm{PG}_{\mathrm{K}}$ and $\mathrm{E}-\mathrm{PG}_{\mathrm{M}}$ formation masses gypsum cement, whose composition was $80 \%$ E-PG + $10 \%$ Portland cement $+10 \%$ opoka. The formation mixture mass properties are given in Table 3.

Mechanical E-PG activation and neutralization of admixtures was preformed in an impact centrifugal disintegrator DIA - 01 with the activating discs rotating a $3000 \mathrm{rpm}$ at opposite directions.

$\mathrm{X}$ - ray diffraction pattern analysis was conducted by using a DRON - 1 difractometer with the following characteristics: anode $-\mathrm{Cu}$, voltage $-30 \mathrm{kV}$, current $8 \mathrm{~mA}$, filter $-\mathrm{Ni}$, goniometer slits $-0.5 ; 1.0 ; 0.25 \mathrm{~mm}$, gonometer counter rotation speed $-2 \% \mathrm{~min}$.

Microscopic investigations were conducted using a Scanning electron microscopy "Stereoscan SH - 10".

Unactivated E-PG and mechanically activate E-PG mixture $\mathrm{pH}$ control was preformed by using a portable $\mathrm{pH}$ meter (model pH - 330i), the solids and distilled water ratio was $1: 10$.

The initial and final setting time was measured with a Vicat instrument. 
Table 4. Ecobalance indices of materials used for constructing a building

\begin{tabular}{l|c|c|c|c|c|c|c|c}
\hline $\begin{array}{l}\text { Group of } \\
\text { materials }\end{array}$ & $\begin{array}{c}\text { Energy } \\
\text { expenditures, } \\
\mathrm{kWh} / \mathrm{m}^{2}\end{array}$ & $\begin{array}{c}\mathrm{CO}_{2} \\
\text { emissions, } \\
\mathrm{kg} / \mathrm{m}^{2}\end{array}$ & $\begin{array}{c}\text { Amount of } \\
\text { energy expendi- } \\
\text { tures } / \mathrm{CO}_{2} \\
\text { emissions based } \\
\text { on the whole, } \%\end{array}$ & $\begin{array}{c}\text { Amount of } \\
\text { construction } \\
\text { materials } \\
\text { used, } \mathrm{t}\end{array}$ & $\begin{array}{c}\text { Percentage } \\
\text { of used } \\
\text { materials, } \\
\%\end{array}$ & $\begin{array}{c}\text { Material } \\
\text { group } \\
\text { mean } \\
\text { density, } \\
\mathrm{kg} / \mathrm{m}^{3}\end{array}$ & $\begin{array}{c}\text { Evaluated } \\
\text { material } \\
\text { group } \\
\text { coefficient }\end{array}$ & $\begin{array}{c}\text { Material } \\
\text { group } \\
\text { usefulness } \\
\text { coefficient }\end{array}$ \\
\hline Metals & 723.7 & 325.6 & 42.4 & 818 & 5.62 & 7000 & 11.7 & 88 \\
\hline $\begin{array}{l}\text { Inorganic } \\
\text { materials }\end{array}$ & 477.4 & 214.8 & 28 & 13525 & 92.95 & 2100 & 3.5 & 1.05 \\
\hline $\begin{array}{l}\text { Synthetic } \\
\text { organic } \\
\text { polymers }\end{array}$ & 400 & 180 & 23.5 & 115 & 0.79 & 800 & 1.3 & 38.6 \\
\hline $\begin{array}{l}\text { Organic } \\
\text { natural } \\
\text { polymers }\end{array}$ & 104 & 46.8 & 6.1 & 93 & 0.64 & 600 & 1 & 9.53 \\
\hline$\Sigma$ & 1705.1 & 767.3 & 100 & 14551 & 100 & - & & - \\
\hline
\end{tabular}

* included for an objective evaluation of density. It allows to evaluate the differences in density for various groups of materials

The measurement of physical and mechanical specimen properties was done on casted bars $(4 \times 4 \times 16 \mathrm{~cm})$ from the formation mixtures. The specimens were hardened in a disiccator above water.

The specimen's properties were determined on samples dried at $60{ }^{\circ} \mathrm{C}$ till constant weight and as well as for those soaked in water after a 7 and 28 days hardening period.

\section{Results and discussions}

\subsection{Construction material ecobalance investigation}

After completion of a construction material production energetic expenditures analysis of construction materials used for one concrete building (Scheuer et al. 2003), it was found, that if we take into account the nature of the raw material, energetic expenditures and pollution emissions into the environment, they will differ very sharply (Table 4).

The use of metals and synthetic materials for construction purposes is growing constantly at the present time. These materials have higher production energy expenditures and the $\mathrm{CO}_{2}$ emissions into the environment which are sharply higher than for corresponding inorganic materials. As we can see from the data in Table 4, the use of metals in the building is only $5.62 \%$, while the energy expenditures to manufacture this amount of metals as well as the $\mathrm{CO}_{2}$ emissions amount into the environment reaches $42.4 \%$. A reverse view is seen when inorganic materials are used - it's construction expenditures reaches almost $93 \%$, while the energy expenditures are only $28 \%$.

To properly evaluate the data provided in this table, it is expedient to include a coefficient appraising the material groups' usefulness from an environmental pollution point of view. This coefficient was determined by multiplying the $\mathrm{CO}_{2}$ emission (\%) by the material group's density influence evaluation coefficient and dividing it by the amount of materials (\%) used in the building. It is evident, that the importance of this coefficient is lower if less energy is used and less $\mathrm{CO}_{2}$ is emitted for the materials applied during production.
It is possible to affirm, after conducting these calculations, that the most effective materials from the energetic usefulness and environmental protection point of view are inorganic materials. If we want to decrease production energy expenditures and pollutant emissions into the environment, we need to look for methods, how to increase inorganic material (sand, gravel, cement, ect.) use and especially of technogenic inorganic waste. Also we need to lower the use of synthetic materials and metals.

Ecobalance comparative analysis of analogical purpose materials used for partition walls are given in Fig. 2. Here we can find integral energy expenditures, including raw material extraction, transportation, benification, article formation as well as production energy expenditures.

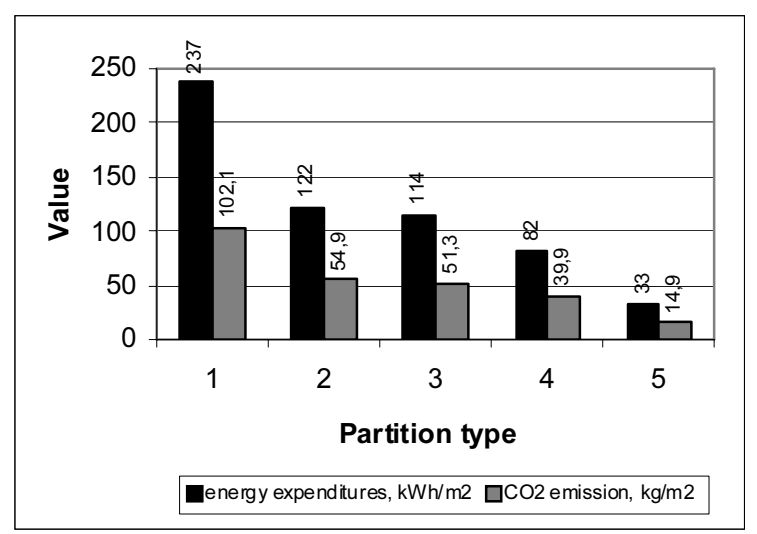

Fig. 2. Ecobalance indice effectiveness comparative data for various materials used in partitions: 1 - ceramic blocks (Vegytė, Kaminskas 2004); 2 - autoclave cellular concrete (Marbach 1989); 3 - silicate block masonry (Marbach 1989); 4 - opoka cement blocks (Frühwald 1994); 5 - gypsum cement (made using E-PG) blocks (reprocessing investigation results are presented in section 3.2.)

Note: data are given for $25 \mathrm{~cm}$ load - bearing construction layer winterproofed with a $10 \mathrm{~cm}$ polystyrene heat insulating layer 
After an analysis of scientific papers (Vegyte, Kaminskas 2004; Marbach 1989; Frühwald et al. 1994) and our investigation results, it was determined that the best results from an economical and ecological point of view are achieved by using mechanically activated E-PG binder (gypsum cement).

Construction regulation norms in Lithuania require that the calculated thermal resistance should be not less than $3.5 \mathrm{~W} /\left(\mathrm{m}^{2} \mathrm{~K}\right)$. If such a thermal resistance is applied to masonry partitions, then the wall's thickness without insulation increases considerably (e.g. autoclave cellular concrete partitions - up to $60 \mathrm{~cm}$ ).

Taking into account the exiting construction norm requirements from an ecological and economical point of view, it is most efficient to use a twin - layer wall construction made-up of a load-bearing part and a heat insulating layer. The highest energy expenditures and $\mathrm{CO}_{2}$ emissions parts for such two-layer constructions fall on the load-bearing part and depend on the nature of the materials which make it up. The authors (Vegytè, Kaminskas 2004) demonstrated, that the energy expenditures in one-layer exterior partition construction material production are 3-4 times greater, than for multi-layer partitions using heat insulating materials.

The number of proposals to include the main ecobalance indices into standards and norms alongside the common requirements are increasing and should be taken into consideration during article certification (Frühwald et al. 1994; Marbach 2006).

Materials should be certified by evaluating the amount of energy used for its production and amount of pollutant emissions into the environment and also during maintenance.

\subsection{Technological E-PG reprocessing investigations}

During the analysis of E-PG reprocessing into constructing materials possibilities, first of all we analyzed the influence of carbonate opoka on E-PG hardening and other properties (Table 5).

As we can see in Table 5, carbonate opoka is a sufficiently effective E-PG acidic media neutralizing additive. The $\mathrm{CaCO}_{3}$ present in opoka in a liquid medium decomposes forming $\mathrm{Ca}(\mathrm{OH})_{2}$ and $\mathrm{CO}_{2}$ gas. It was found that the opoka additive only slightly increases the specimen's strength. This indicates that the silicic acid present in opoka and reaction with $\mathrm{Ca}(\mathrm{OH})_{2}$, when calcium hydrosilicates are formed during the first 28 days at ambient temperatures goes on very slowly and almost does not increase the strength of the hardening system.
The gypsum cement formed specimen properties are given in Table 6. Specimens were formed by using unactivated $\mathrm{E}-\mathrm{PG}_{\mathrm{K}}$ and $\mathrm{E}-\mathrm{PG}_{\mathrm{M}}$ for comparison. Also investigations were conducted, which indicated the possibility to form and obtain large dimension blocks on an industrial scale (Fig. 3).

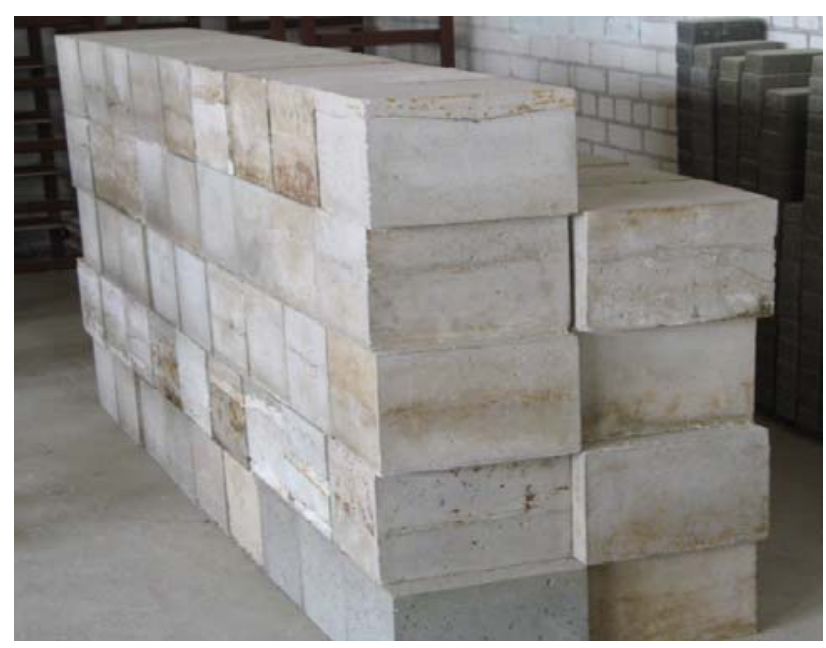

Fig. 3. Blocks made using E-PG

Specimens made using unactivated E-PG without additives showed very low-strength values and high water absorption. This can be explained by the fact, that without destruction of primary porous crystalline E - PG structure hydration and hardening blocking acidic admixtures are left in it.

It was found that the mechanical activation process and nature of raw materials have an influence on specimen physical and strength properties. Gypsum cement made with $\mathrm{E}-\mathrm{PG}_{\mathrm{M}}$ showed a higher density and a lower water absorption level; its strength was $12-15 \%$ higher and the decrease in strength after soaking in water reached only $12 \%$, while in the case for gypsum cement made using $\mathrm{E}-\mathrm{PG}_{\mathrm{K}}$, it was $20 \%$. Such a sharp difference between $\mathrm{E}-\mathrm{PG}_{\mathrm{K}}$ and $\mathrm{E}-\mathrm{PG}_{\mathrm{M}}$ gypsum cement specimens can be explained by the formation of calcium hydrate silicates. During Portland cement hardening the calcium ions react with silicic acid, forming calcium hydrated silicates. The amount of $\mathrm{SiO}_{2}$ in $\mathrm{E}-\mathrm{PG}_{\mathrm{M}}$ reaches $4.76 \%$ (Table 2), while it does not form in $\mathrm{E}-\mathrm{PG}_{\mathrm{K}}$. Thus we can assume, that part of the $\mathrm{SiO}_{2}$ in $\mathrm{E}-\mathrm{PG}_{\mathrm{M}}$ is in a soluble state allowing for additional amounts of calcium hydrated silicates to be formed, thus creating a denser and stronger structure.

Table 5. Influence of opoka additive on $\mathrm{E}-\mathrm{PG}_{\mathrm{K}}$ properties

\begin{tabular}{c|c|c|c}
\hline Properties & \multirow{2}{*}{ Density, $\mathrm{kg} / \mathrm{m}^{3}$} & \multicolumn{2}{|c}{ Strength properties (after 7/28 days) } \\
\cline { 4 - 4 } & & $\mathrm{R}_{\text {comp }}, \mathrm{MPa}$ & $\mathrm{R}_{\text {bend }}, \mathrm{MPa}$ \\
\hline Formation mass composition & 1.69 & $12.4 / 12.6$ & $5.02 / 5.12$ \\
\hline Activated E-PG & 1.74 & $12.2 / 12.3$ & $5.11 / 5.06$ \\
\hline $\mathrm{E}-\mathrm{PG}_{\mathrm{K}}+3 \%$ opoka & 1.70 & $12.9 / 12.8$ & $5.36 / 5.81$ \\
\hline $\mathrm{E}-\mathrm{PG}_{\mathrm{K}}+5 \%$ opoka & 1.76 & $12.8 / 13.1$ & $6.25 / 6.54$ \\
\hline $\mathrm{E}-\mathrm{PG}_{\mathrm{K}}+10 \%$ opoka & 1.81 & $13.1 / 13.0$ & $6.17 / 6.51$ \\
\hline $\mathrm{E}-\mathrm{PG}_{\mathrm{K}}+15 \%$ opoka & & & \\
\hline
\end{tabular}


Table 6. Unactivated E-PG and gypsum cement specimen properties

\begin{tabular}{|c|c|c|c|c|c|c|c|}
\hline \multirow{3}{*}{$\begin{array}{l}\text { Formation mass } \\
\text { composition }\end{array}$} & \multicolumn{2}{|c|}{ Physical properties } & \multicolumn{4}{|c|}{ Strength properties (after $7 / 28$ day hardening period) } & \multirow{3}{*}{$\begin{array}{l}\text { Softening coeffi- } \\
\text { cient after } 7 / 28 \text { day } \\
\text { hardening period }\end{array}$} \\
\hline & \multirow{2}{*}{$\begin{array}{l}\text { Density, } \\
\mathrm{kg} / \mathrm{m}^{3}\end{array}$} & \multirow{2}{*}{$\begin{array}{l}\text { Water absorb- } \\
\text { tion, } \%\end{array}$} & \multicolumn{2}{|c|}{ Dry specimens } & \multicolumn{2}{|c|}{ Moist specimens } & \\
\hline & & & $\begin{array}{l}\mathrm{R}_{\text {comp. }} \\
\mathrm{MPa}\end{array}$ & $\begin{array}{l}\mathrm{R}_{\text {bend. }} \\
\mathrm{MPa}\end{array}$ & $\begin{array}{l}\mathrm{R}_{\text {comp. }} \\
\mathrm{MPa}\end{array}$ & $\begin{array}{l}\text { R } \text { bend. } \\
\mathrm{MPa}\end{array}$ & \\
\hline $\begin{array}{l}\text { E-PG } \mathrm{PG}_{\mathrm{K}} \text { without } \\
\text { additives }\end{array}$ & 1040 & 23.6 & $1.2 / 1.8$ & $1.1 / 1.2$ & $0.4 / 0.5$ & - & $0.33 / 0.28$ \\
\hline $\begin{array}{l}\mathrm{E}-\mathrm{PG}_{\mathrm{M}} \text { without } \\
\text { additives }\end{array}$ & 1090 & 20.6 & $1.6 / 2.1$ & $1.4 / 1.4$ & $0.6 / 0.8$ & - & $0.43 / 0.38$ \\
\hline $\begin{array}{l}\text { Gypsum cement } \\
\text { made using E-PG }\end{array}$ & 1750 & 7.9 & $\begin{array}{c}18.6 / 22 \\
3 \\
\end{array}$ & $7.1 / 9.8$ & $14.9 / 18.1$ & $5.8 / 8.1$ & $0.80 / 0.81$ \\
\hline $\begin{array}{l}\text { Gypsum cement } \\
\text { made using E-PG }\end{array}$ & 1790 & 7.6 & $20.9 / 25.6$ & $7.7 / 10.7$ & $18.6 / 22.2$ & $6.3 / 9.6$ & $0.88 / 0.87$ \\
\hline
\end{tabular}

In the general case, gypsum binding materials are composed of particles possessing different energetic levels due to various structural defects. Here, the active centres are made-up of oxygen groups with unsaturated valence bonds, due to which they distinguish themselves by a high reactivity.

The natural physical-chemical gypsum reacting surface allows to bond water molecules by forming hydroxide ions (Коровяков 2003). This phenomena becomes more clearly expressed, when the primary E-PG structure is shattered during mechanical activation.

The primary porous E-PG structure was destructed during mechanical activation by impact centrifugal method. Acidic hydration and hardening blocking liquid are liberated and neutralized by the Portland cement and opoka mixture. Then a gel-like hydrate silicate forms during the gypsum cement hardening period which is decisive for the formation of a nano structural diffusion layer which limits the transportation of water into the gypsum crystallization zone. As time goes on, these nano structural layers can form the general arising $\mathrm{CaSO}_{4}$. $\mathrm{nH}_{2} \mathrm{O}$ crystal structure. The practically insoluble compounds $\left(\mathrm{Al}(\mathrm{OH})_{3}, \mathrm{Fe}(\mathrm{OH})_{3}, \mathrm{Fe}(\mathrm{OH})_{2}, \mathrm{Si}(\mathrm{OH})_{4}, \mathrm{Mg}(\mathrm{OH})_{2}\right)$ formed during neutralization cover the just formed $\mathrm{CaSO}_{4}$ - $0.5 \mathrm{H}_{2} \mathrm{O}$ crystals with a nano structural diffusion layer, the properties of which have an influence on specimen hydration and hardening kinetics. Depending on the nano structural layer formation conditions and kinetics, the E-PG hydration and hardening as well as the formation of new structures could be regulated and controled.

The formation of nano structure presumption was confirmed by X-ray diffraction pattern analysis (Fig. 4), which demonstrated that in activated E-PG specimens no bassanite was found, while in the case of gypsum cement the peaks of unhydrated gypsum were sufficiently distinct. The presence of bassanite in gypsum cement specimens after 28 day hardening period can be explained by a formation of a nano structural layer. Also, sharp bassanite peaks were found in specimens hardened for 3 months. When the specimen was milled and additionally hydrated, the bassanite peaks did not disappear. So, we can assert that at higher gypsum cement densities the water molecules which entered the calcium coordination sphere could possess crystalographic bonds with several calcium ions.
Thus the bassanite structure remains partly unchanged and the tobermorite gel being formed in the hardening system together with the crystalline gypsum structure forms a dense, strong gypsum cement stone. Hence we can assertain taking into account this data, that the unreacted E-PG and gypsum cement specimen hardening mechanisms differ radically.
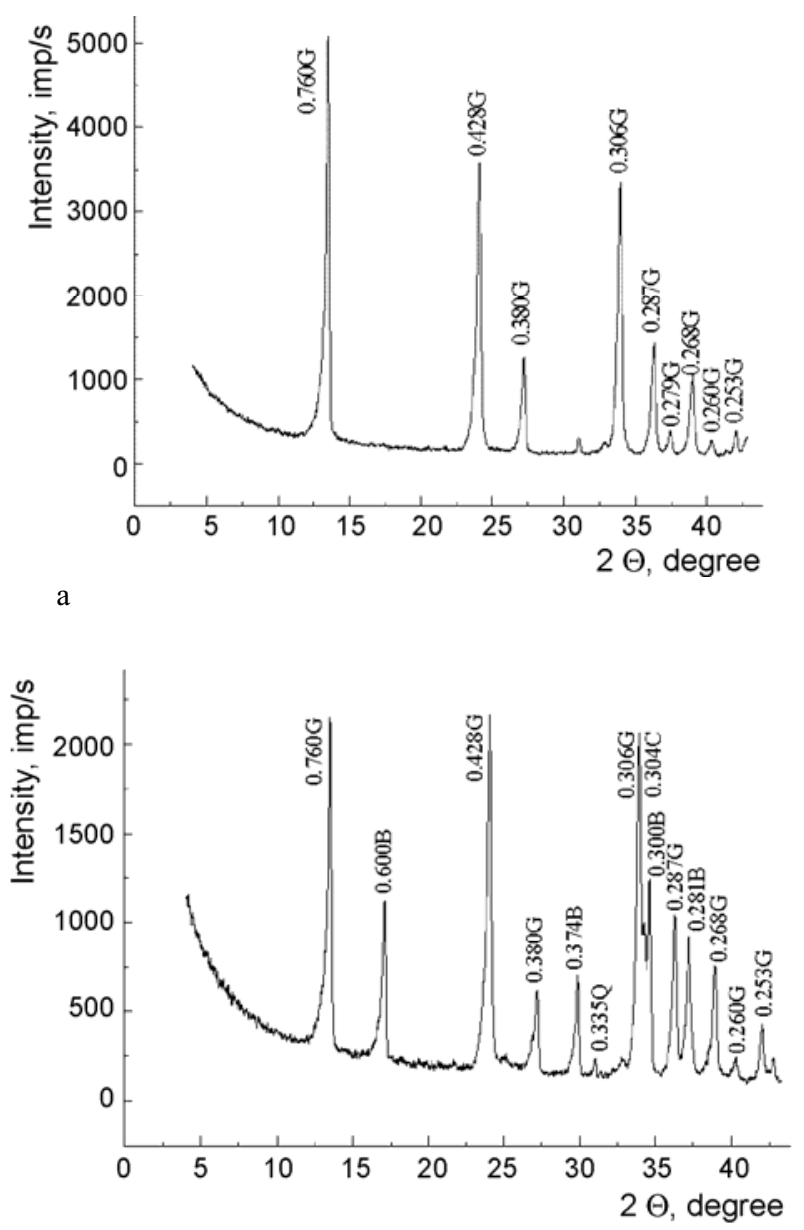

b

Fig. 4. X-ray diffraction patterns of specimens hardened for 28 days. a - pure activated E-PG, b - activated E-PG with $10 \%$ Portland cement and $10 \%$ opoka. G gypsum; B - basanite; Q - quartz; C - calcite 


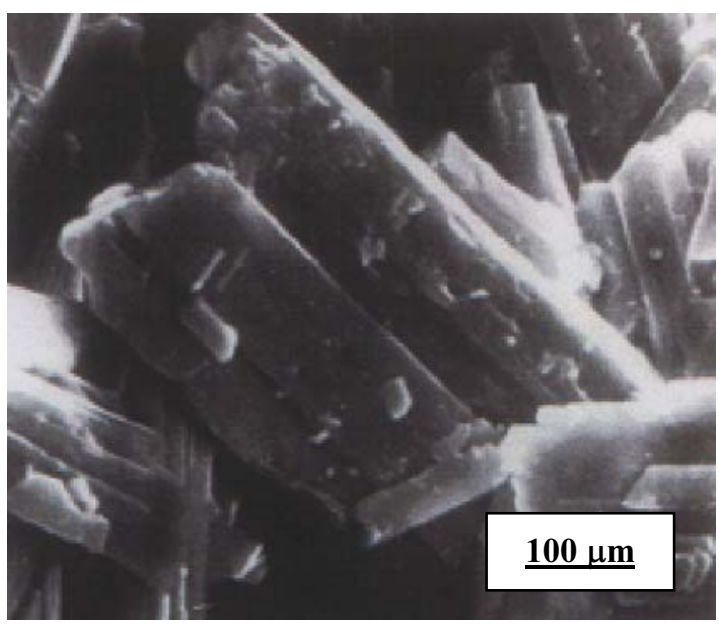

a

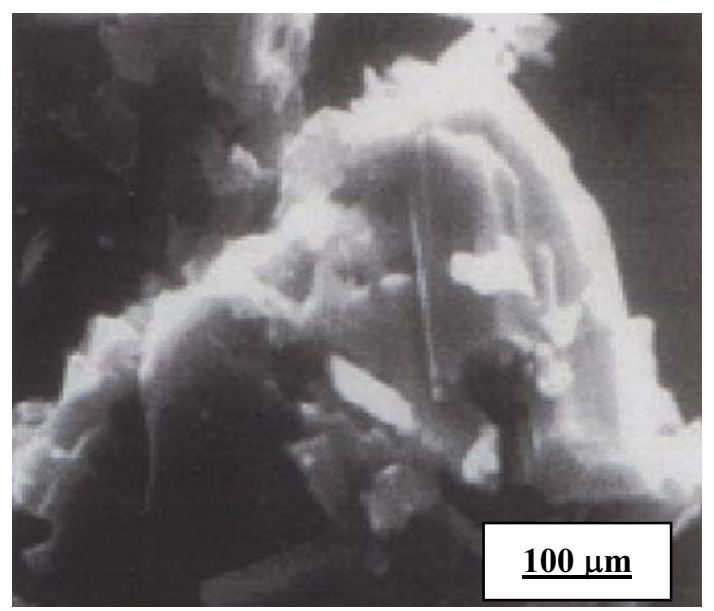

b

Fig. 5. Phosphogypsum crystals: a - microstructure of mechanically activated $\mathrm{CaSO}_{4} \cdot \mathrm{nH}_{2} \mathrm{O}$ without additives; $\mathrm{b}$ - microstructure of $\mathrm{CaSO}_{4} \cdot \mathrm{nH}_{2} \mathrm{O}$ modified with Portland cement and opoka additive

The formation of nano structural layers on growing gypsum crystals hypothesis was confirmed by microscopic (Fig. 5) as well as by electrical conductivity measurements.

As we can see from Tables 5, 6, we can obtain strong, water-resistant articles based on E-PG, if we select the proper neutralizing and modifying additives which in the future can replace energy consuming analogical purpose articles (silicate, ceramic blocks, etc). The compressive strength of phosphogypsum blocks allow them to be used as constructive, load-bearing articles.

We can say on the basis of the investigation results, that the neutralizing additives can be divided into 2 groups: those with a distinquished specific hardening property and not. Additives having a specific hardening property and neutralizing property (Portland cement) during hardening in the system $\mathrm{CaSO}_{4}-$ additive- $\mathrm{H}_{2} \mathrm{O}$ increases the gypsum binding materials strength (up to
$25 \mathrm{MPa}$ ) and also improves other physical and mechanical properties. Additives not processing specific hardening properties (opoka) are able only to neutralize the acidic E-PG media and do not take part in the hardening process without any larger influence on physical and mechanical properties (compressive strength is up to $13 \mathrm{MPa})$.

After investigation of soluble acidic E-PG admixture reductions in gypsum cement after mechanical activation, we found that the amount of $\mathrm{P}_{2} \mathrm{O}_{5 \mathrm{w} . \mathrm{s}}$ in gypsum cement specimens was about 10 times lower than in comparison with unactivated initial E-PG; for $\mathrm{F}_{\mathrm{w} . \mathrm{s}}-4$ times.

\section{Conclusions}

1. It was determined, that the most effective materials according to their nature, are mineral ones from the energetic usefulness and environmental protection point of view. There is a need to search for methods how to increase inorganic material use, especially those made from technogenic inorganic waste, if we want to lower energy expenditures and pollutant emissions.

2. It was found, that after an analytical ecobalance investigation of different analogical purpose materials, the best results were obtained by using the waste material - extractive hemihydrate phosphogypsum. Its use allows to increase the wall partitions energetic usefulness and to lower the amount of energy used during production as well as pollutant emissions into the environment. E-PG reprocessing energy expenditures are 3-6 times lower than for other analogical purpose and properties wall materials and at the same time a lower environmental pollution is achieved.

3. The laboratory and pilot plant E-PG reprocessing investigations showed, that the use of mechanical activation method and proper selection of acidic E-PG media neutralizing additives makes it possible to reprocess the most abundant waste material in Lithuania into construction purpose gypsum materials. Articles manufactured from E-PG can replace building wall partitions made using ceramic, silicate and other energy consuming articles.

4. All the entire acidic E-PG media neutralizing additives can be divided into those with and without specific hardening properties. Those with the distinquished hardening property during hydration in a system $\mathrm{CaSO}_{4}-$ additive $-\mathrm{H}_{2} \mathrm{O}$ add some strength (up to $25 \mathrm{MPa}$ ) and improve other physical and mechanical properties. Additives, not processing specific hardening properties and only able to neutralize the acidic E-PG media, do not influence the specimen's physical and mechanical properties. The use of specific hardening additives allows for calcium hydrated silicate formation determined by nano structural diffusion layers, which lowers water molecule diffusion into the gypsum crystal's growth zone and deposits it on growing gypsum crystal surfaces. Depending on nano structural layer formation conditions and kinetics, it could be regulated and controled by E-PG hydration and hardening, as well as new structure formation processes. 


\section{References}

Buchanan, A. H; Honey, B. G. 1994. Energy and carbon dioxide implication of building construction, Energy and Building 20: 205-217.

Čiurpinskas, K.; Martinaitis, V. 1997. Pirminès energijos poreikių statybinèms medžiagoms nustatymo ypatumai [Determination of primary energy needs for construction materials], Statyba [Civil Engineering] 3(11): 35-44.

Čygas, D.; Laurinavičius, A. 2003. Statybinès atliekos ir ju panaudojimo tiesiant lietuvos kelius galimybių analizé [Study of construction waste and feasibility study of its utilization for road construction in Lithuania], Journal of Environmental Engineering and Landscape Management 11(2): 60-65.

Debnath, A.; Singh, S. K.; Singh, Y. P. 1995. Comparative assesment of energy requirements for different types of residental buildings in India, Energy and Building 23: 141-146.

Degirmenci, N. 2008. Utilization of phosphogypsum as raw and calcined material in manufacturing of building products, Construction and Building Materials 22(8): 1857-1862.

Degirmenci, N.; Okucu, A.; Turabi, A. 2007. Application of phosphogypsum in soil stabilization, Building and Environment 42(9): 3393-3398.

De Oliveira, L. A. P.; De Castro Gomes, J. P.; Cristiana, Pereira, N. G. 2006. Study of sorptivity of self-compacting concrete with mineral additives, Journal of Civil Engineering and Management 12(3): 215-220.

Dzenajavičienè, E. F. 2001. Vietinis ir atsinaujinantis kuras šilumos ūkyje: būklè ir kliūtys plètrai [Local and renewable fuel in the heating economy: its condition and obstacles for development], in 3-oji tarptautine šilumines energetikos ir aplinkos apsaugos konferencija $\left[3^{\text {rd }}\right.$ International heat energy and environmental protection conference], Vilnius, Lithuania, 2001, 14-18.

Frühwald, A.; Wegener, G.; Krüger, S. Beudert, M. 1994. Holz - ein Rohstoff der Zukunft, D. G. F. H.: 16-20.

Gedgaudas, M.; Martinaitis, V. 1996. Daugiaaukščiu gyvenamuju pastatų šildymo sistemu renovavimo efektyvumo ivertinimas [Apartment house heating system renovation effectiveness evaluation], Energetika [Power Engineering] 2: 31-39.

Gimbutaitè, I.; Venckus, Z. 2008. Air pollution burning different kinds of wood in small power boilers, Journal of Environmental Engineering and Landscape Management 16(2): 97-103.

Hums, D. 1994. Darstellung der Ökobilanz für einen modernen Baustoff. Weimar: Ibausil: 32.

Jakowlew, G.; Lasis, A.; Kolodov, V.; Rats, Y. 1997. Struktur mit der ionisiertem Wasser angemachten Gipsashekompositionen, 13 Internationale Baustofftagung 2: 461-468.

Kaminskas, A. 2002. Energija tausojančiu statybiniu medžiagu technologijos [Energy saving technologies of building materials]. Vilnius: Technika. 257 p. ISBN 9955-9328-4-8.

Kaminskas, A.; Gaidučis, S.; Mačiulaitis, R. 2007. Extractive influence of granulated milled slag glass additive on hemihydrate phosphogypsum hardening, Materials Science 13(3): 224-228.

Kaminskas, A.; Kaminskas, R. 2003. Energy saving utilization technology of glass waste, in Proc. of International Conference, Vilnius, Lithuania, 2003. Vilnius: Technika: 41-46.
Kaziliūnas, A.; Bačauskienè, M. 2007. Dehydration of phosphogypsum and neutralization of its impurities in the steam of raised pressure, Materials Science 13(1): 57-60.

Kohler, N. 1986. Analyse energetique de la construction, utilization at demalition de batiments. These No. 623. Lausanne: EPFL.

Kosior-Kazberuk, M.; Lelusz, M. 2007. Strength development of concrete with fly ash addition, Journal of Civil Engineering and Management 13(2): 115-122.

Kryževičienė, A., Jasinskas, A., Žaltauskas, A. 2001. Atsinaujinančiu energijos šaltiniu žemès ükyje paieška [Search for renewable energy sources in agriculture]. Žemdirbystė [Agriculture]. LŽI Scientific Research Papers: 201-214.

Marbach, H. 1989. Bauen in Weiß, Arbeitsgruppe Porensteine der Kalks und Stein Industrie. 76 p.

Marbach, H. 2006 "Porit" Gasbeton nach DIN 4165/66. Das Umfassende Konzept für die Hochbau, Kalks und Steinwerke GmbH, 53-73.

Martinaitis, V. 1997. Pastato gyvavimo ciklo termodinaminio vertinimo veiksniai [Building's life cycle thermodynamical evaluation factors], Statyba [Civil Engineering] 3(7): $75-84$.

Martinaitis, V. 1999. Energijos tausojimo galimybès ir investiciju poreikis daugiabučiuose namuose [Energy-saving possibilities and investment needs for apartment houses], in Tarptautinès mokslinès konferencijos medžiaga [Proc. of international scientific conference]. Klaipeda, Lithuania, 85-90.

Radwan, M. M.; Heikal, M. 2005. Hydration characteristics of tricalcium aluminate phase in mixes containing $\beta$-hemihydrate and phosphogypsum, Cement and Concrete Research 35(8): 1601-1608.

Rimkevičius, M. 2003. Gipscementis iš mechaniškai aktyvuoto ekstrakcinio pushidratinio fosfogipso [Gypsum cement from mechanically activated hemihydrate phosphogypsum] Doctoral dissertation. Vilnius: Technika. $88 \mathrm{p}$.

Rimkevičius, M.; Kaminskas, A. 2003. Mechaniškai aktyvinto ekstrakcinio pusvandenio fosfogipso savybès [Properties of mechanically activated phosphogypsum], Journal of Civil Engineering and Management 9(1): 49-54.

Rudžionis, Ž.; Ivanauskas, E. 2004. Investigations into effective fly ash used in concrete, Journal of Civil Engineering and Management 10(4): 303-309.

Scheuer, C.; Keoleian, G. A., Reppe, P. 2003. Life cycle energy and environmental performance of a new university building: modelling challenges and design implications, Energy and Building 35: 1049-1064.

Singh, M. 2002. Treating waste phosphogypsum for cement and plaster manufacture, Cement and Concrete Research 32(7): 1033-1038.

Singh, M. 2003. Effect of phosphatic and fluoride impurities of phosphogypsum on the properties of selenite plaster, $\mathrm{Ce}$ ment and Concrete Research 33(9): 1363-1369.

Suzuki, M; Oka, T; Okada, K. 1995. The estimation of energy consumption and $\mathrm{CO}_{2}$ emission due to housing construction in Japan, Energy and Building 22: 165-169.

Šeduikytė, L.; Bliūdžius, R. 2005. Pollutants emission from building materials and their influence on indoor air quality and people performance in offices, Journal of Civil Engineering and Management 11(2): 137-144.

Vegytė, N.; Kaminskas, A. 2004. Energijos sąnaudu ir aplinkos taršos mažinimo tendencijos statybinių medžiagu pramonejje [A tendency to a decrease of energy demand and en- 
vironmental pollution in the production of building materials], Energetika [Power engineering] 3: 26-29.

Žurauskas, R. 2002. Technologiniu veiksniu itaka termoizoliacinio kompozito iš putu cementbetonio ir putu polistireno savybems [Influence of technological factors on foam cement concrete and polystyrene heat insulating composite properties]. Doctoral dissertation. Vilnius: Technika. $90 \mathrm{p}$.
Žvironaite, J.; Gaidučis, S.; Kaminskas, A.; Mačiulaitis, R. 2008. Hydration and hardening of composite binder containing mechanically activated hemihydrate phosphogypsum, Materials Science 14(4): 356-360.

Коровяков, В. Ф. 2003. Гипсовые вяжущие и их применение в строительстве [Koroviakov, V. F. The gypsum binding materials and their usage in building], Российский химический журнал [Russian journal of chemistry] 47(4): 18-25.

\section{PUSHIDRAČIO FOSFOGIPSO PERDIRBIMO İ GIPSINES RIŠAMĄSIAS MEDŽIAGAS EKOBALANSO YPATUMAI IR REIKŠME}

\section{S. Gaidučis, R. Mačiulaitis, A. Kaminskas}

\section{Santrauka}

Klasifikuojant ir grupuojant medžiagas pagal žaliavų kilmę ir gaminių paskirti atlikti lyginamieji medžiagų energinio naudingumo ir jų gamybos ekobalanso analitiniai tyrimai. Nagrinėtos ir lygintos energijos sąnaudos ir teršalų patekimas į aplinką analogiškos paskirties medžiagoms gauti. Tirtos vienos iš perspektyviausių ekonomoniu ir ekologiniu požiūriu technogeninès atliekos - ekstrakcinio pushidračio fosfogipso (E-PG) savybès. Nustatyta, kad energijos poreikis gaminant analogiškos paskirties medžiagas iš esmès skiriasi. Žaliavos kilmè turi ịtaką produkcijos energiniam naudingumui. Efektyviausios pagal kilmę energinio naudingumo ir aplinkosaugos požiūriu yra mineralinès medžiagos, ypač jeigu jos pagamintos iš technogeninių neorganinių atliekų. Geriausi rezultatai energiniu ir ekologiniu požiūriu gauti naudojant atliekų žaliavą - E-PG. Jo perdirbimo energijos sąnaudos ir teršalų emisija i aplinką yra kelis kartus mažesnès, negu gaminant kitas analogiškos paskirties ir savybių sienines medžiagas, be to, mažeja aplinkos tarša. Ateityje gaminiai iš perdirbto E-PG galètų pakeisti pastatu atitvaroms naudojamus keraminius, silikatinius ir kitus energijai imlius dirbinius.

Reikšminiai žodžiai: fosfogipsas, rūgščiosios priemaišos, neutralizuojantys priedai, mechaninè aktyvacija, gipscementis, energinis naudingumas, ekobalansas.

Sergejus GAIDUČIS. PhD student (since 2005), Dept of Building Materials, Vilnius Gediminas Technical University (VGTU), Lithuania. Research interests: gypsum binding materials.

Romualdas MAČIULAITIS. Prof. Dr. Habil. Dept of Building Materials, Vilnius Gediminas Technical University (VGTU), Lithuania. Research interests: synthesis of various materials and its properties.

Antanas KAMINSKAS. Prof. Dr. Habil., Vilnius Gediminas Technical University (VGTU) Institute of Thermal Insulation, Lithuania. Research interests: construction materials and its production ecobalance, environmental protection. 